\title{
Analyzing Mainstreams In Current Performance Management Studies And Its Relationship With HR And Other Practices: A Literature Review
}

\author{
Muhammad Tresnadi Hikmatª Ina Primiana ${ }^{a}$, Dermawan Wibisono ${ }^{b}$ \\ ${ }^{a}$ Department of Economics and Business, Padjajaran University, 40193 Bandung, Indonesia \\ ${ }^{b}$ School of Business and Management, bandung Institute of Technology, 40132 Bandung, Indonesia \\ *Corresponding author: mtresnadihikmat@gmail.com
}

\begin{abstract}
This paper is to identify the mainstreams that are associated with performance management research in the HR and other fields to give clear guidance for future study that will give guidance for performance management research by further studying the PM mainstream that will then contribute to business and academic field. The research is done by conducting systematic literature review of several current papers discussing variety aspects of performance management practices in HR and other fields, by limiting only on the current mainstreams. Based on that limitation, this paper does not discuss either the relationship between the mainstreams or the effects of an existence of PMS on performance of a company. From the research it is found that there are several mainstreams on performance management based on current papers and it also noted that good performance of a company is not necessarily a result from an implementation of a Performance Management System (PMS) but just good practices of human resources, knowledge management and others. Further studies can be done to analyze the relationships between the mainstreams and find methodologies to develop effective models of PMS considering the features and studied mainstreams.It also can study the basic effectiveness of PMS implementation compared to using other toolsets such as knowledge management.
\end{abstract}

Keywords: Performance management system (PMS); HR performance measurement; Dashboards; PMS mainstream

(c) 2016 Penerbit UTM Press. All rights reserved

\subsection{INTRODUCTION}

Performance management system (PMS) has played an important role in managing organization performance over time towards desired goals (Carpineti, 2008). Neely et al., 1995 defined performance measurement as "the process of quantifying the efficiency and effectiveness of action". Other papers discussed how performance management can be aimed to reflect organizational culture and philosophy (Medori \& Steeple (2000).

Performance management system can be defined as a mean of delivering sustained success through strategic and integrated process by developing the performance of workers or staffs and by individual and team's capabilities for improvement (Armstrong, 2000). And to understand PMS, we must also understand the steps of a performance management system that consist of four phases which are design, implementation, use and review (Bourne et al.,2000).

One of the findings on previous PMS study concludes that they only focused on financial measures where in a sense are short-term and agreed upon as lagging indicators and are not proactive to indicate the present and future (Browne and Devlin, 1998 ; Medori and Steeple, 2000). Therefore later studies found that top performing organizations are those balancing financial and non-financial measures and linking strategies with measures of operations (Neely, 1999). An approach on balancing the perspectives was also studied.

The Balanced scorecard did not only balanced the financial with non-financial measures, but conducts translation of organization's mission and strategy into comprehensive set of performance measures that provides the framework for strategic measurement and a management system (Kaplan and Norton,1996).

Over the years studies on performance management focused on various area of interests especially on its applications such as for management accounting (Otley,1999), in the field of marketing (Ambler et al.2004) and production management (Chen and Liaw, 2006). In operations management it was noted that orientation of PMS conventionally was headed for controlling productivity and cost of production (De Toni and Tonchia, 2001). The measurements in operations are so important that Neely et al., 1995 described "performance measurement as the process of quantifying action, where measurement is the process of quantification and action correlates with performance".

Furthermore several challenges arise when implementing PMS. For example various critical issues emerged during implementation phase, mainly as consequence of tensions between different performance dimensions and the need for creativity, alternative integrating mechanisms such as direct intervention of founder and social interaction (Giovannoni and Maraghini, 2013). While a study specifically discussed the role of PMS as a managerial instrument for public research centers (Agostino et al.,2012), another study found that due to structural differences between traditional and extended enterprise, the measurement model of a PMS would structurally be different (Bititchi et al ,2005). Therefore 
that study proposed a model for measuring and managing performance with intrinsic and extrinsic inter-enterprise coordinating measures. Other studies of implementation are such as the banking sector (Munir et al., 2013), and manufacturing sector (Lin et al., 2014).

Out of the few studies, there are studies mentioning the role of performance dashboards where you can see clear associations of key features of the drill down analysis and scenario analysis with user's productivity (Latinen and Yigitbasioglu, 2012). But this study did not propose any standardization of performance dashboards.

Other study suggests business analytics play an important role in a successful PMS implementation. The study by Schlafke et al., 2013 clarifies possible applications of business analytics and their advantages for organizational performance management. The study finds that effective performance management area has cross sections for IT, strategic management, and pushing the needs for analytic methods has become an imperative component of PMS in a dynamic competitive business environment.

There was a study that identifies gaps in terms of usefulness and academic research, suggest solutions in form of conceptual framework to improve measurement (Choong, 2013). Other studies specifically study the evaluation of impact areas within the organization using Balanced Scorecard (BSC) framework model which has structured steps and specific techniques of analysis (Franceshini et al., 2013) There are also a study of competitive strategy that positively and significantly enhances firm performance through performance measurement (Teeratansirikool et al., 2013).

However these studies have limitations such as they are case study of limited number of companies or have not studied impact between the factors. Nor that these studies have not captured the mainstreams of performance management and measurement that could give clear insights to further studies. These papers also did not emphizise that certain fields outside of performance management have individual impact of performance such for example human resources.

This paper will discuss systematically review papers related to those issues. And it would also identify it and define it as mainstreams that would give insight to further research in the PMS field.

\subsection{LITERATURE REVIEW}

Performance management systems has several aspects the must exist and must also give a robust and effective output of productivity. There are several important aspects of performance management such as the framework, alignment with corporate strategy, fostering process improvement, flexibility, and the ease to be monitored.

Performance management system was studied several years and has come up with several findings. Neely (2002) studied that performance management perspectives must consider stakeholder's satisfaction while other studies mentioned that performance management perspectives to be measured are not just financial but must be balanced with non-financial perspectives such as customer, internal process and learning and growth (Kaplan et.al 1992,1996, 2001).

Several known frameworks of performance management systems:

1) Performance Measurement Matrix (Keegan et al,.1989)

2) The performance measurement questionnaire (Dixon et al,1990)

3) The SMART performance pyramid (Lynch and Cross, 1991)

4) Performance for World Class Manufacturing (Maskell, 1991)

5) Quantum Performance Measurement Model (Hronec, 1993)

6) The Balance Scorecard (Kaplan and Norton,1996)

7) Performance Prism (Neely and Adams, 2000)

8) Integrated Performance Management System (Wibisono and Khan, 2002)

9) Six Sigma Business Scorecard (Gupta, 2004)

These frameworks gave variety of insights on the shifted needs of performance management systems that measures a single aspect of perspective (i.e. financial) to basically other nonfinancial aspects such as customer, internal process and learning and growth (Kaplan and Norton,1996). The needs to consider stakeholder's satisfaction and other perspective in a form of prism (Neely,2002).

As Bourne et al.,(2000) mentioned the steps of a performance management system which consists of four phases which are design, implementation, use and review. Specifically in the design phase, Marr and Schiuma (2003) found that there are several contributors in the design of performance management systems areas of subjects including accounting, economics, management, operations, marketing, finance, human resources, organizational behavior and also in higher education management.

There have also been studies that do comparative literature study on performance management. Choong (2013) tried to understand the features of PMS and identified gaps in terms of usefulness and academic research; suggest solutions in form of conceptual framework to improve measurement. The study utilized a systematic approach in reviewing and examining existing PMS and Non-PMS Articles focus on features of measurement.

However these studies haven't contributed solid evidence of how specific features of a PMS system should be designed, implemented that will contribute effectiveness to strategic goals in short term and create a leap of process improvement.

But before reaching there, the study to classify recent mainstreams developed in performance management study has an urgency to be discussed. This will contribute to the ideas for creating framework thinking to where the development of performance management studies could further go. 


\subsection{METHODOLOGY}

This paper conducts systematic literature review which compares methodology, key findings, limitations and future research of papers that are discussing performance management and other papers that gives ideas to develop an ideal performance management system. This will then qualitatively find key findings to propose deeper research in the field.

The method to give output of this study is combining several methods of research that can provide clear and sharp assessment after the data processing phase. The literature review will be conducted in the form of systematic literature review (SLR) which conducts review in a process that consists several steps before reaching the finding and conclusions. There are six basic steps of SLR including scoping study, definition of search protocol, application of exclusion criteria, data extraction, analysis and dissemination (Tranfield et al.,2003)

Scoping study is ensuring that the area of research is well defined that will encapsulate the area of review from reaching beyond the boundaries. In this study performance management shall be the define scope. The search protocol is the guidance of search which explains the procedure and search terms that shall be utilized. Exclusion criteria are an important phase to differentiate and create distinction of search items in the scope. Data extraction is collecting the data that an moving it into a prepared fields in a table. The process is conducted by skimming through the literature article and search for keywords related to the prepared fields such as : findings, methodology, limitations of research and future research. The last phase is conduct an analysis and dissemination of data. In this phase we extract the data according the similarities or mainstreams which we are looking for. For example the literatures that discuss key success factors of PMS implementations shall be discussed as subtopic in the findings and discussion section.

The first phase of literature study is setting search parameters to get the best results to the last three years as the basis of the Scopus indexed journals and also other current journals from Proquest and Google Scholar. The scoping of the search as a search protocol are using the search keyword "performance management and performance measurement" with range of three years before. This will collect and justify the urgency and needs for research based on current studies. The collected papers are then mapped into a table as shown in the appendix of this paper.

The dissemination of data will results the collection of key findings and future research which combined will be analyzed and defined as the mainstreams of the study. These identified mainstreams are then explained as the findings of this paper.

\subsection{RESULTS AND DISCUSSION}

\section{Mainstreams in Performance Management Studies}

After the dissimination of data phase, there are three mainstream identified in this study as mentioned in Table 1 below :

Table 1 The Mainstream in Performance management system

\begin{tabular}{|l|l|l|l|}
\hline No & Mainstream of PMS & Key Characteristics & Prominent Authors \\
\hline 1 & $\begin{array}{l}\text { Dashboards and } \\
\text { Informations Systems } \\
\text { Features }\end{array}$ & $\begin{array}{l}\text { Aspects of performance dashboards } \\
\text { that must be present }\end{array}$ & $\begin{array}{l}\text { Latinen and Yigitbasioglu, 2012 (2012); Schlafke } \\
\text { et al.,(2013) }\end{array}$ \\
\hline 2 & $\begin{array}{l}\text { Performance Management } \\
\text { Systems Customization }\end{array}$ & $\begin{array}{l}\text { Different features and components of } \\
\text { Performance Management System }\end{array}$ & $\begin{array}{l}\text { Bititchi } \text { et al.,(2005); Jaaskelainen and Laihonen, } \\
\text { (2013); Teeratansirikool et al (2013); Waal } \text { et al., } \\
\text { (2013); Hwang } \text { et al., (2013); Krechovska and } \\
\text { Prochazkova (2014); Arena et al., (2014); } \\
\text { Choong (2013); Rhodes et al.,(2012) }\end{array}$ \\
\hline 3 & $\begin{array}{l}\text { Key Initiatives and } \\
\text { Indicators Measured }\end{array}$ & $\begin{array}{l}\text { Different Key Indicators of of } \\
\text { performance management and and and } \\
\text { effective initiatives }\end{array}$ & $\begin{array}{l}\text { Koike (2012); Conaty (2012); Kazemi and } \\
\text { Andersen,(2013); Franceshini et al., (2013); } \\
\text { Giovannoni and Maraghini, (2013); Munir } \text { et al } \\
\text { (2013); Lin } \text { et al., (2014) }\end{array}$ \\
\hline
\end{tabular}

The details of the findings for each paper are mentioned on Appendix 1 Resume of Literature Review on Performance Management. Each mainstreams are discussed as follow.

\section{Dashboards and Information Systems Features}

Studies in this first mainstream discusses that performance management system which succeeds are followed by the implementation of an information systems or dashboards. A study confirms that there are clear associations key features of the drill down analysis of a dashboard system and scenario analysis with user productivity (Latinen and Yigitbasioglu, 2012). Another study emphizise that applications of business analytics and their advantages for organizational performance management (Schlafke et al., 2013). This study also mentions that effective performance management area has cross sections for IT, Strategic Management, Analytical Methods. Because of the dynamic Competition in business environment there is push in the needs for analytics (Schlafke et al., 2013).

Future research in the area of mainstream is developing standard dashboard criteria, measurement item, Industry and the development of Dashboard Component models.

\section{Performance Management Systems Customization}

The second identified mainstream is there are papers that clearly indicate that different features and components of PMS will have different impacts on the outcome of the company. This is named as performance management systems customizations. 
An example of the study are as shown in a study of performance measurement at extended enterprises (Bititchi et al.,2005).This explains collaborative architecture of an extended enterprise means that structural differences between traditional and extended enterprise, the measurement model would also structurally be different. Therefore this paper proposed a model for measuring and managing performance with intrinsic and extrinsic inter-enterprise coordinating measures.

Other studies in this mainstream results the evaluation of a proposed measurement approach which provides understanding of their potential in different workplaces such as in knowledge intensive organizations. (Jaaskelainen and Laihonen 2013) The study finds that PMS supports not only measurement practices but the overall performance of the organization.

Results of studies in the mainstream of PMS customization also found that competitive strategy positively and significantly enhance firm performance through performance measurement (Teeratansirikool et al., 2013). There is also a need of benchmarking as a customization of PMS by calculation of performance metrics (Hwang et al., 2013) Another paper finds that the Bouckaert and Halligan framework for analyzing public sector performance management is useful, with some modifications, it was also observed that absent political crisis/commitment, governments will prioritise "external" performance measures such as customer service, participation and transparency objectives over "internal" performance measures such as financial, staff management and whole of government reporting. (Rhodes et al.,2012)

Krechovska and Prochazkova,(2014) implied that more than half of enterprise do not work with sustainability with corporate strategy and corporate management and effects of sustainability activities into corporate performance measurement and management regardless of enterprise size. Assessment of similarities and potential synergies between Risk Management Systems and PMS and (Arena et al., 2014) can be an important aspect for customization of PMS.

\section{Key Initiatives and Indicators Measured}

The third identified mainstream in this study are that when implementing performance management systems, the choice in determining the indicators to be measured and the actions namely initiatives taken will determine the success of implementation. An example a study confirms that market demand correlates to green product innovation and firm performance (Lin et al., 2014).

Koike (2012) finds that Asian governments introduce many varieties of Performance Management Systems but other factors are essential such as public involvement. But there are other things such as good Governance and the importance of data integrity to measure performance management.

Other studies indicates that the detection of early warning signals in projects can be better enabled through the application of performance measurement system with properly defined key performance indicators (Kazemi and Andersen,2013) While many sets of indicators are usually able to meet the role of PMS, they may exert a different impact on context they are applied (Franceshini et al., 2013). Giovannoni and Maraghini, (2013) discusses that various critical issues emerged during implementation phase, mainly as consequence of tensions between different performance dimensions and the need for creativity, alternative integrating mechanisms such as direct intervention of founder and social interaction. While Conaty (2012) studied that there are five organizational characteristics/attributes are identified as central to the understanding of challenges in performance management such as inter-stakeholder relationships, tensions across priority objectives, cultural and institutional clashes, power distribution and interdependent stress. Nevertheless we must look into important initiatives when implementing PMS. In the banking sector it was found that although major catalyst of change were the financial lost experienced, major regulatory changes and the appointment of the new board of directors and president are also the initiative for PMS execution (Munir et al .,2013).

All the above mentioned studies support key measurement indicators and initiatives in performance management systems that are eligible for further studies. They will contribute to further research in relationships between the discovered performance management mainstreams.

After discussing the mainstreams on performance management studies, this paper has an urgency to discuss other fields that have impact on organizational performance but indicated no emphasis on having or implementing a performance management system.

\section{HR, Knowledge Management and Other Aspects Related to Performance and PMS}

Besides findings of mainstreams of performance management, there are also other studies that supports the argumentation that activities related to human resources, knowledge management, and other has also significant impact on performance of company and indicates no involvement of any type of performance management system(PMS). But there are also studies that a PMS has an effect on the practices of other fields such as human resources.

Basically an excellent practice of human resources management will improve performance of an organization. A paper not has not only proved that a good management of human resources affects the improvement of the performance, but also explained the ways that the organization can improve its performance (Lokaj \& Xhemajli, 2014). The results provide strong support for the hypothesis that the involvement of human resource functions into the business and corporate strategy reduces employee turnover rate and enhances financial performance (Tamer Khalil \& Singh, 2013).

A study suggests that a performance management system (PMS) can be the key factor determining whether an organization can manage its human resources effectively. This research affirms that when employees' expectations are not met, inappropriate job behavior and performance can derail the attainment of an organization's goals. When implemented well, a good PMS would provide critical information that would allow an organization to make sound decisions regarding their human resources (Singh \& Twalo, 2015)

Another study in performance management identified three key benefits (strategy execution, process efficiency, and fact-based decisionmaking) and ten inhibiting barriers under respective project and organizational dimensions.(Yeoh, Richards, \& Wang, 2014) Other study suggest that mission statement, HR strategies and goal setting have a critical role in describing performance management strategies. (Shahmehr, Safari, Jamshidi, \& Yaghoobi, 2014).The article reviews the mission statement, strategies and operational goal setting role in performance management in hospitals throughout a combined approach of quantitative and qualitative research. Statistical and contextual analysis helps us to examine the priority of each factor. Still regarding corporate strategy, another study implies that leader skills have an effect not only on the choice of the adoption of strategic management, but also on the contribution of strategic management to firm 
performance. It performs an empirical investigation into the moderating effect of leader skills on the relationship between strategic management and global performance.(Jaoua \& Radouche, 2014)

In the field of small medium enterprise (SME) it was proven that human resources management (HRM) practices have significant impact on business performance at $1 \%$ level of significance. That paper concluded that, for small businesses to grow, and build up the required capacity for promotion of sustainable national economic development, the adoption of HRM practices by SME operators should be encouraged.(Ojokuku, Sajuyigbe, \& Ogunwoye, 2014)

While in the field of knowledge management and intellectual capital, studies show that they will impact performance of an organization. A study results show: that good knowledge management and the cloud technology investment of Taiwan-listed communications network companies have a significant positive interaction effect on organizational performance, which also implies that an increase in cloud technology investment plays a role in the positive enforcement of improving organizational performance.(Huang, 2014)

Leadership styles has always been important and a study conducted a survey and found a direct positive relationship between leadership style and organizational performance and an indirect relationship between leadership style and human resource strategy as a mediator, while human resource strategies contribute positively and significantly to organizational performance. The findings are relevant for operating human resource management strategies and for developing a style of leadership.(Alsughayir, 2014)

Another interesting finding also shows that there is a positive and strong correlation between ethics and organizational performance. The relationship between ethics and knowledge creation processes is also positive and significant but no significant relationship is observed between knowledge creation processes and organizational performance.(Akhavan, Ramezan, Jafar Yazdi, \& Mehralian, 2014)

\subsection{CONCLUSION}

This paper finally concludes that there mainstreams of PMS study which are confirmed using the systematic literature review. The mainstreams are : dashboards and information Systems Features, performance management systems Customization, and Key Initiatives and Indicators Measured. It shows that a PMS must consider important aspects such as standardization of dashboards, how the PMS should be customized to special needs of a business and industry and what key indicators and initiatives which should be carried out.

The study also concludes that although there are many cases PMS implementation which effects the practice of human resources, strategy development. It is also proven that several factors alone will impact performance without any little or no indication of performance management practices.

This study will give new grounds of in-depth research in the field of performance management and measurement that will then contribute to business and academic field. The limitation of the study are the amount of papers studied has impact on the mainstreams discovered meaning that more papers can develop more mainstreams.

Further studies can analyze the relationships and methodologies to develop effective models of PMS considering the features and the already identified mainstreams. And also the urgency to differentiate performance results of an organization implementing and not implementing a performance management system which further can measure the effectiveness or ineffectiveness of a PMS.

\section{References}

Agostino, D., Arena, M., Azzone, G., Dal Molin, M., \& Masella, C. (2012). Developing a performance measurement system for public research centers. International Journal of Business Science and Applied Management, 7(1), 43-60.

Akhavan, P., Ramezan, M., Jafar Yazdi, M., \& Mehralian, G. (2014). Exploring the relationship between ethics, knowledge creation and organizational performance. VINE, 44(1), 42-58. doi: http://dx.doi.org/10.1108/VINE-02-2013-0009

Alsughayir, A. (2014). Human Resource Strategies as a Mediator between Leadership and Organizational Performance. International Business Research, 7(3), 91-100. Ambler,T.,Kokkinaki,F., and Puntoni,S.(2004) "Assessing Marketing Performance: Reasons for Metrics Selection", Journal of Marketing Management, 20(3/4), 475498

Arena,M.,Arnaboldi,M.(2014) Risk and Performance Management: are they easy partners? Management Research Review, 37(20),.153-166

Ariyachandra,T.R., and Frolick, M.N.(2008) "Critical Success Factors in Business Performance Management-Striving for success", Information Systems Management, 25(2),.113-120

Armstrong, M. (2000). Performance Management-Key Strategies and Practical Guidelines (2nd ed.). London: Kogan Page.

Bititci,U.S; Mendibil,K;Martinez,V; Albores,P. (2015) Measuring and Managing Performance in Extended Enterprises. International Journal of Operations and Production Management, 25(4), 333-353

Bourne,M.,Mills,J.,Wilcox,M.,Neely,A.,Platts,K.(2000) "Designing implementing and updating performance measurement systems. International Journal of Performance Measurement, 20(7),754-771

Browne, J., \& Devlin, J. (1998). Performance measurement: The ENAPS Approach. University College Galway: Ireland.

Carpineti, L. C. R., Galdamez, E. V. C., \& Gerolamo, M. C. (2008). A measurement system for managing performance of industrial clusters-A conceptual model and research cases. International Journal of Productivity and Performance Management, 57, 405-419. http://dx.doi.org/10.1108/17410400810881854

Choong,K.K.(2013) Understanding the features of performance measurement system: a literature review. Measuring Business Excellence, 17(4), 102-121

Conaty F.J.,(2012)Performance management challanges in hybrid NPO/public sector settings:an Irish Case. International Journal of Productivity and Performance Management, 61(3), 290-309

Dessomlert,S.and Sawmong,S.(2013) Factors, influencind service innovation and business performance of spa for health in thaiand, and emperical study, International Journal of Business, Marketing and Decision Science, 6(1), 136-156

Dixon, J.R., Nanni, A.J., \& Vollmann, T.E. (1990). The New Performance Challenge - Measuring Operations for World-class Competition. Dow Jones-Irwin, Homewood, IL

Franceshini,F.,Galletto,M.,Turina,E.(2013) Quality Paper: Techniques for impact evaluation of performance measurement systems. International Journal of Quality \& Reliability Management, 30(2), 197-220

Frank, U., Heise,D., Kattenstroth,H.(2009) Use of Domain Specific Modeling language for realizing versatile Dashboards, University of Duiburg-Essen Universitaetsstr.Essen Germany

Giovannoni E., Maraghini M.P.(2013) The Challanges of Integrated Performance measurement systems. Integrating mechanisms for integrated measures. Accounting, Auditing \& Accountability Journal, 26(6), 978-1008

Gupta , Praveen (2004). The Six Sigma Business Scorecard. McGraw Hill, Second Edition

Hronec, S.M. (1993). Vital Signs- Using Quality, Time and Cost performance measurement to chartyour company's future 
Huang, C.-L. (2014). The Effects of Knowledge Management on Organizational Performance of Taiwan Listed Communication Network Companies: Using Cloud Technology Investment as the Moderator. Journal of Global Business Management, 10(2), 117-130.

Hwang,B.-G.,Tan, H.F.,Sathish, S.(2013) Capital project performance measurement and benchmarking in Singapore Engineering. Construction and Architectural Management. 20(2),143-159

Jaaskelainen,A.and Laihonen,H.(2013) Overcoming the specific performance measurement challenges of knowledge intensive organizations. International Journal of Productivity and Performance Management,62(4), 350-363

Jaoua, F., \& Radouche, T. (2014). The Moderating Role of Leader Skills on the Relationship between Strategic Management and Global Performance: An Empirical Study. International Business Research, 7(8), 59-72.

Kaplan, R.S. \& Norton, D.P. (1996). Using the balanced scorecard as a strategic management system. Harvard Business Review. January-February, 75-85.

Kaplan,R.S. and Norton,D.P(1992),"The balanced scorecard-measures that drive performance", Harvard Business Review, 70, 71-9

Kaplan,R.S. and Norton,D.P(1996), The Balanced Scorecard, Harvard Business School Press, Cambridge,MA

Kaplan,R.S. and Norton,D.P(2001). The Strategy Focused Organization: How Balanced Scorecard Companies Thrive in the New Business Environment. Harvard Business School Press, Cambridge,MA

Kazemi, S.H.,Andersen,B.,(2013) Application of performance measurement as an early warning system. A case study in the oil and gas industry. International Journal of Managing Projects in Business, 6(4), 714-738

Keegen, D.P.,Eiler,R.G.,and Jones,C.R(1989) "Are your performance measures obsolete?",Management Accounting,70(12), 45-50

Koike,O.(2013) Institutionalizing performance management in Asia: looking East or West. International Journal of Public Sector Management. 25(5), 347-360

Krechovska,M., Prochazkova, P.T., (2014) Sustainability and Its Integration into Corporate Governance Focusing on Corporate Performance Management and Reporting. Procedia Engineering, 69(2014), 1144-1151

Laitinen,O.V.,Yigitbasioglu,O.M.,(2012) The Use of Dashboards in Performance Management: Evidence from Sales Managers. The International Journal of Digital Accounting Research, 12, 39-58

Lin,R.J.,Tan,K.H.,Geng,Y.(2012) Market demand, green product innovation, and firm performance: evidence from Vietnam motorcycle industry. Journal of Cleaner Production, 40(2013), 101-107

Lokaj, A. S., \& Xhemajli, A. (2014, 2014/12/19/ 2014 Dec 19). The Impact Of Human Resources Management On Work Performance - Case Study Beer Factory Peje/Kosove, Varazdin.

Lynch, R.L., \& Cross, K.F. (1991). Measure Up: Yardsticks For Continuous Improvement.Cambridge: Blackwell Publishers.

Marr, B., \& Schiuma, G. (2003). Business performance measurement-past, present and future. Management Decision, 41, 680-687. http://dx.doi.org/10.1108/00251740310496198

Maskell, Brian H. (1991). Performance Measurement for World Class Manufacturing: A Model for American Companies. Productivity Press

Medori, D., \& Steeple, D. (2000). A framework for auditing and enhancing performance measurement systems. International Journal of Operations \& Production Management, 20, 520-533. http://dx.doi.org/10.1108/01443570010318896

Minichiello, V., Aroni, R., Timewell, E., \& Alexander, L. (1995). In-Depth Interviewing: Principles, Techniques, Analysis (2nd ed.). Melbourne: Longman Australia Pty. Ltd.

Munir,R.,Baird,K.,Perera,S.(2013) Performance measurement system change in an emerging economy bank. Accounting, Auditing \& Accountability Journal , 26(2), $196-233$

Neely, A. (1999) The performance measurement revolution: why now and what next? International Journal of Operations \& Production Management, University of Cambridge, UK: MCB University Press, 19(2), 205-228.

Neely, A., \& Adams, C. (2000) Perspectives on Performance: The Performance Prism. In Bourne, M. (ed.). Handbook of Performance Measurement, London: Gee Publishing.

Neely,A., Gregory,M., Platts,K., (1995) "Performance measurement system design: A literature review and research agenda", International Journal of Operations \& Production Management, 15(4), 80 - 116

Ojokuku, R. M., Sajuyigbe, A. S., \& Ogunwoye, A. B. (2014). Human Resource Management Practices And Small Scale Business Performance: Evidence From Osun State, South Western Nigeria. Journal Of Emerging Trends in Economics and Management Sciences, 5(7), 1-6.

Otley,D.(1999) "Performance management: A framework for Management Control Systems Research", Management Accounting Research, 10(4), 363-382

Rhodes M.L., Biondi, Lucia; Gomes, Ricardo; Melo, Ana I; Ohemeng, Frank (2012) Current state of public sector performance management in seven selected countries. International Journal of Productivity and Performance Managemen, 61(3), 235-271.

Sarantakos, S. (1998) Social Research (2nd ed.). South Melbourne: MacMillan Education Australia.

Schlafke,M.,Silvi,R.,Moller,K.,(2013) Reflective Practice A framework for business analytics in performance management. International Journal of Productivity and Performance Management,62(1), 110-122

Shahmehr, F. S., Safari, N., Jamshidi, M. J., \& Yaghoobi, N.-M. (2014). The Impact of Performance Management on Mission Statement and Operational Goal Setting. International Journal of Business and Management, 9(11), 189-198.

Singh, P., \& Twalo, T. (2015). Effects Of Poorly Implemented Performance Management Systems On The Job Behavior And Performance Of Employees. The International Business \& Economics Research Journal (Online), 14(1), 79.

Tamer Khalil, D., \& Singh, S. (2013). Does strategic human resource involvement and devolvement enhance organisational performance? International Journal of Manpower, 34(6), 674-692. doi: http://dx.doi.org/10.1108/IJM-01-2012-0003

Teeratansirikool,L.,Siengthai,S.,Badir,Y., and Charienngam,C.(2013) Competitive strategies and firm performance: the mediating role of performance measurement International Journal of Productivity and Performance Management, 62(2), 168-184

Tranfield,D.,Denyer,D.,Smart,.P(2003) Towards a Methodology for Developing Evidence Informed Management Knowledge by means of Systematic Review, British Journal of Management, 14, 207-222

Wibisono, D., \& Khan, M. (2002a). A framework of performance measurement system design for manufacturing, Advances in Business Paradigms and Supporting Technologies. Proceedings of the 18th International Conference on CAD/CAM, Robotics and Factories of the Future, July 3-5, Porto, Portugal

Yeoh, W., Richards, G., \& Wang, S. (2014). Benefits And Barriers To Corporate Performance Management Systems. The Journal of Computer Information Systems, 55(1), 105-116. 


\section{Appendix}

Appendix 1 Resume of Literature Review on Performance Management

\begin{tabular}{|c|c|c|c|c|}
\hline Authors & Methods & Key Findings & Limitations & Future Research \\
\hline Latinen et al (2012) & $\begin{array}{l}\text { empirical study by } \\
\text { surveying companies in } \\
\text { finland using dashboards }\end{array}$ & $\begin{array}{l}\text { - there are clear associations of } \\
\text { key features of the drill down } \\
\text { analysis and scenario analysis } \\
\text { with user productivity }\end{array}$ & $\begin{array}{l}\text {-the limitation of the study } \\
\text { relates the sample size which } \\
\text { was small due to response } \\
\text { from non-dashboard users. } \\
\text {-the paper doesn't emphasize } \\
\text { the quality of the dashboard }\end{array}$ & $\begin{array}{lr}\text { - developing } & \begin{array}{r}\text { standard } \\
\text { dashboard }\end{array} \\
\text { criteria, } \\
\text { measurement } & \text { item, } \\
\text { industry } & \\
\text {-dashboard } & \text { component } \\
\text { models } & \end{array}$ \\
\hline Schlafke et al (2013) & $\begin{array}{lr}\text { employs literature based } \\
\text { analysis for this } \\
\text { conceptual } & \text { argument } \\
\text { established } & \end{array}$ & $\begin{array}{l}\text { - clarifies possible applications of } \\
\text { business analytics and their } \\
\text { advantages for organizational } \\
\text { performance } \\
\text { - effective panagement. } \\
\text { management area has cross } \\
\text { sections for it, strategic } \\
\text { management, analytical methods } \\
\text { - dynamic competition in business } \\
\text { environment pushes the needs for } \\
\text { analytics }\end{array}$ & $\begin{array}{l}\text { - no specific item of } \\
\text { measurement to measure the } \\
\text { PMS } \\
\text { - no clear standard dashboard } \\
\text { for PMS has been discussed }\end{array}$ & $\begin{array}{lr}\text { - defining an appropriate } \\
\text { analytical method for } \\
\text { measuring } & \text { PMS } \\
-\quad \text { developing } & \text { standard } \\
\text { dashboard r criteria, } \\
\text { measurement } \\
\text { industry } \\
\text {-PMS model must consider } \\
\text { business analytics }\end{array}$ \\
\hline Koike (2013) & $\begin{array}{l}\text { scholarly analysis of } \\
\text { performance } \\
\text { management and analysis } \\
\text { of government and } \\
\text { reports from international } \\
\text { bodies }\end{array}$ & $\begin{array}{l}\text { - Asian governments introduce } \\
\text { many varieties of performance } \\
\text { management systems but other } \\
\text { factors are essential such as public } \\
\text { involvement. } \\
\text { - good governance and the } \\
\text { importance of data integrity to } \\
\text { measure performance } \\
\text { management is important }\end{array}$ & $\begin{array}{l}\text { must have more details of } \\
\text { variable linkage }\end{array}$ & $\begin{array}{l}\text { gives insights to PMS } \\
\text { model for a sector } \\
\text { (industry). in this case } \\
\text { government }\end{array}$ \\
\hline Bititchi et al (2005) & $\begin{array}{l}\text { reviews literature in } \\
\text { performance } \\
\text { measurement and } \\
\text { extended enterprises and } \\
\text { explains collaborative } \\
\text { architecture of an } \\
\text { extended enterprise. } \\
\text { using case study to } \\
\begin{array}{l}\text { develop a model for } \\
\text { measuring }\end{array}\end{array}$ & $\begin{array}{l}\text { due to structural differences } \\
\text { between traditional and extended } \\
\text { enterprise, the measurement } \\
\text { model would structurally be } \\
\text { different. therefore there this } \\
\text { paper propose a model for } \\
\text { measuring and managing } \\
\text { performance with intrinsic and } \\
\text { extrinsic inter-enterprise } \\
\text { coordinating measures }\end{array}$ & $\begin{array}{l}\text { this study is a case base study } \\
\text { therefore there must be further } \\
\text { cases and samples }\end{array}$ & $\begin{array}{l}\text { a study to develop the } \\
\text { model for performance } \\
\text { measurement for extended } \\
\text { enterprise }\end{array}$ \\
\hline
\end{tabular}




\begin{tabular}{|c|c|c|c|c|}
\hline Authors & methods & key findings & limitations & future research \\
\hline Lin et al (2014) & $\begin{array}{lr}\text { empirical study } & \text { on } \\
\text { market demand against } \\
\text { innovation and } & \text { firm } \\
\text { performance } & \text { with } \\
\text { constructs } & \text { economic } \\
\text { performance, } & \text { firm } \\
\text { performance, } & \text { green } \\
\text { products, environmental } \\
\text { performance }\end{array}$ & $\begin{array}{l}\text { market demand correlates to green } \\
\text { product innovation and firm } \\
\text { performance }\end{array}$ & $\begin{array}{llr}\text { limitations } & \text { focus } & \text { on } \\
\text { motorcycle } & \text { industry } & \text { in } \\
\text { Vietnam } & & \end{array}$ & $\begin{array}{l}\text { how we can make a } \\
\text { framework ror } \\
\text { performance management }\end{array}$ \\
\hline $\begin{array}{l}\text { Krechovska } \\
\text { al(2014) }\end{array}$ & $\begin{array}{l}\text { a questionnaire method } \\
\text { used among Czech small, } \\
\text { medium sized, and large } \\
\text { enterprise }\end{array}$ & $\begin{array}{l}\text { - more than half of enterprise do } \\
\text { not work with sustainability with } \\
\text { corporate strategy and corporate } \\
\text { management } \\
\text { - Czech enterprise do not include } \\
\text { the effects of sustainability } \\
\text { activities into corporate } \\
\text { performance measurement and } \\
\text { management regardless of } \\
\text { enterprise size }\end{array}$ & $\begin{array}{l}\text { focus of study are in Czech } \\
\text { enterprises }\end{array}$ & $\begin{array}{l}\text { further research will focus } \\
\text { on methods and metrics } \\
\text { enterprise could use in } \\
\text { measuring environmental } \\
\text { and social business } \\
\text { activities }\end{array}$ \\
\hline Arena et al (2014) & $\begin{array}{l}\text { literature review, } \\
\text { highlighting points of } \\
\text { contract between Risk } \\
\text { Management System } \\
\text { (RMS) and PMS along } \\
\text { three dimensions : scope } \\
\text { of system, measurement } \\
\text { and ownership }\end{array}$ & $\begin{array}{l}\text { assessment of similarities and } \\
\text { potential synergies between RMS } \\
\text { and PMS and possible avenues for } \\
\text { future research }\end{array}$ & $\begin{array}{l}\text { limitations are the amount of } \\
\text { data reviewed }\end{array}$ & $\begin{array}{l}\text { possible instruments and } \\
\text { organizational } \\
\text { arrangements that could be } \\
\text { exploited and implications } \\
\text { of different possible } \\
\text { configurations }\end{array}$ \\
\hline Choong (2013) & $\begin{array}{l}\text { systematic approach in } \\
\text { reviewing and examining } \\
\text { existing PMS and non- } \\
\text { PMS articles focus on } \\
\text { features of measurement }\end{array}$ & $\begin{array}{l}\text { identify gaps in terms of } \\
\text { usefulness and academic research, } \\
\text { suggest solutions in form of } \\
\text { conceptual framework to improve } \\
\text { measurement }\end{array}$ & $\begin{array}{l}\text { no conceptualized features } \\
\text { reached beyond normative } \\
\text { reasoning }\end{array}$ & $\begin{array}{l}\text { recommendation for future } \\
\text { research regarding features } \\
\text { of PMS }\end{array}$ \\
\hline
\end{tabular}




\begin{tabular}{|c|c|c|c|c|}
\hline Authors & Methods & Key Findings & Limitations & Future Research \\
\hline $\begin{array}{l}\text { Giovannoni and } \\
\text { Maraghini (2013) }\end{array}$ & $\begin{array}{l}\text { combines studies on } \\
\text { PMS with empirical } \\
\text { findings related to } \\
\text { monnalisa, a medium } \\
\text { sized Italian family firm }\end{array}$ & $\begin{array}{l}\text { various critical issues emerged } \\
\text { during implementation phase, } \\
\text { mainly as consequence of tensions } \\
\text { between different performance } \\
\text { dimensions and the need for } \\
\text { creativity, alternative integrating } \\
\text { mechanisms such as direct } \\
\text { intervention of founder and social } \\
\text { interaction }\end{array}$ & $\begin{array}{l}\text { the study does not discuss } \\
\text { challenges that actually effect } \\
\text { PMS }\end{array}$ & $\begin{array}{l}\text { further study could discuss } \\
\text { challenges that actually effect } \\
\text { PMS }\end{array}$ \\
\hline Munir et al (2013) & $\begin{array}{l}\text { the study uses } \\
\text { Kasurinen's accounting } \\
\text { change model to explain } \\
\text { management accounting } \\
\text { change as a product of } \\
\text { motivators, catalyst and } \\
\text { facilitators. the model } \\
\text { also focuses on how } \\
\text { confusers, frustators and } \\
\text { delayers inhibit PMS } \\
\text { change and the role of } \\
\text { leaders in the change } \\
\text { process }\end{array}$ & $\begin{array}{l}\text { while uncertain } \begin{array}{c}\text { economic } \\
\text { increasing }\end{array} \\
\text { conditions, } \\
\text { competition, and pressure to } \\
\text { improve performance and enhance } \\
\text { accountability motivated changes } \\
\text { in banks PMS, the major catalyst } \\
\text { of change were the financial lost } \\
\text { experienced, major regulatory } \\
\text { changes and the appointment of } \\
\text { the new board of directors and } \\
\text { president }\end{array}$ & $\begin{array}{l}\text { the study is based on one bank } \\
\text { in an emerging economy }\end{array}$ & $\begin{array}{l}\text { future study may evaluate } \\
\text { how changes in the PMS } \\
\text { influences the performance } \\
\text { and efficiency of the bank. }\end{array}$ \\
\hline Waal et al (2013) & $\begin{array}{l}\text { extensive literature } \\
\text { research and interviews } \\
\text { at } 17 \text { prominent Dutch } \\
\text { organizations }\end{array}$ & $\begin{array}{l}\text { the study found four main } \\
\text { advantages, two } \\
\text { disadvantages and two main } \\
\text { reasons for use of performance } \\
\text { management and measurement } \\
(\mathrm{PMM})\end{array}$ & $\begin{array}{l}\text { the number of participating } \\
\text { organizations and } \\
\text { interviewees could be higher }\end{array}$ & $\begin{array}{l}\text { longitudinal studies would } \\
\text { better examine the } \\
\text { developments and shits in the } \\
\text { relations between PMM } \\
\text { advantages, disadvantages } \\
\text { and reasons for use. }\end{array}$ \\
\hline Hwang et al (2013) & \begin{tabular}{lr}
\multicolumn{2}{l}{ comprehensive literature } \\
review then & a \\
questionnaire & was \\
developed with & 32 \\
contractor & firms \\
participating &
\end{tabular} & $\begin{array}{l}\text { contractors in Singapore do not } \\
\text { practice performance } \\
\text { measurement on a regular basis } \\
\text { and there is no uniformity in } \\
\text { calculation of performance } \\
\text { metrics, leading to low usage of } \\
\text { benchmarking }\end{array}$ & $\begin{array}{l}\text { the low number of companies } \\
\text { which responded and the size } \\
\text { of projects analyzed tended to } \\
\text { focus towards a relatively } \\
\text { small and medium scale }\end{array}$ & $\begin{array}{l}\text { the usage of metrics to } \\
\text { compare project performance } \\
\text { of Singapore with overseas } \\
\text { construction may be } \\
\text { investigated }\end{array}$ \\
\hline
\end{tabular}




\begin{tabular}{|c|c|c|c|c|}
\hline Authors & Methods & Key Findings & Limitations & Future Research \\
\hline $\begin{array}{l}\text { Kazemi and } \\
\text { Andersen (2013) }\end{array}$ & $\begin{array}{l}\text { combination of action } \\
\text { research and semi } \\
\text { structured interviews and } \\
\text { document analysis } \\
\text { supplemented by a post } \\
\text { mortem analysis after } \\
\text { project close-out }\end{array}$ & $\begin{array}{l}\text { detection of early warning signals } \\
\text { in projects can be better enabled } \\
\text { through the application of } \\
\text { performance measurement system } \\
\text { with properly defined key } \\
\text { performance indicators }\end{array}$ & $\begin{array}{l}\text { the case study involved only } \\
\text { one project from the oil and } \\
\text { gas industry }\end{array}$ & $\begin{array}{l}\text { broader investigation } \\
\text { of such systems should } \\
\text { be carried out by } \\
\text { testing in different } \\
\text { projects, in various } \\
\text { organizations and } \\
\text { environments can } \\
\text { provide further insight } \\
\text { into the potential of the } \\
\text { approach and how the } \\
\text { system should be } \\
\text { designed and used }\end{array}$ \\
\hline $\begin{array}{l}\text { Franceshini et al } \\
(2013)\end{array}$ & $\begin{array}{l}\text { approach by impact } \\
\text { reference model derived } \\
\text { from balanced scorecard } \\
\text { (BSC) framework. the } \\
\text { different perspectives of } \\
\text { BSC are interpreted as } \\
\text { areas of impact within } \\
\text { organizations. structured } \\
\text { steps for impact } \\
\text { evaluation are described } \\
\text { and specific techniques } \\
\text { of analysis are introduced }\end{array}$ & $\begin{array}{l}\text { although many sets of indicators } \\
\text { are usually able to meet the role of } \\
\text { PMS, they may exert a different } \\
\text { impact on context they are applied }\end{array}$ & $\begin{array}{l}\text { the application of the method } \\
\text { is based on the assumption } \\
\text { that managers charged with } \\
\text { the analysis have a profound } \\
\text { understanding of the specific } \\
\text { contextual factors. the } \\
\text { methodology does not } \\
\text { consider the possibility of } \\
\text { interaction among different } \\
\text { indicators producing the } \\
\text { impact }\end{array}$ & $\begin{array}{l}\text { future works will } \\
\text { consider the way } \\
\text { correlation among } \\
\text { indicators may be } \\
\text { evaluated and included } \\
\text { in impact analysis. } \\
\text { further developments } \\
\text { will also investigate } \\
\text { specific approaches to } \\
\text { analyze and compare } \\
\text { different impact } \\
\text { profiles }\end{array}$ \\
\hline $\begin{array}{l}\text { Jaaskelainen and } \\
\text { Laihonen (2013) }\end{array}$ & $\begin{array}{l}\text { qualitative case } \\
\text { approach, carried out as } \\
\text { an action research is used } \\
\text { with empirical data } \\
\text { obtained through } \\
\text { interviews, workshops } \\
\text { and analysis of } \\
\text { documentation related to } \\
\text { measurement systems }\end{array}$ & $\begin{array}{l}\text { results of the evaluation of } \\
\text { proposed measurement } \\
\text { approaches provide understanding } \\
\text { of their potential in different } \\
\text { workplaces in knowledge } \\
\text { intensive organizations ins } \\
\text { supports not only measurement } \\
\text { practices but the overall } \\
\text { performance of the organization }\end{array}$ & $\begin{array}{l}\text { customer target oriented } \\
\text { measurement requires long- } \\
\text { term customer relationships } \\
\text { which restricts its applicability } \\
\text { in every knowledge intensive } \\
\text { organization }\end{array}$ & $\begin{array}{l}\text { more detail and } \\
\text { contextual analysis } \\
\text { and practical testing of } \\
\text { measurement } \\
\text { approaches in different } \\
\text { service environments } \\
\text { will contribute to the } \\
\text { discovery of a more } \\
\text { generalizable } \\
\text { measurement } \\
\text { approaches }\end{array}$ \\
\hline $\begin{array}{l}\text { Teeratansirikool et al } \\
\text { (2013) }\end{array}$ & $\begin{array}{l}\text { conducted by mail survey } \\
\text { of Thai listed companies } \\
\text { in } 2009 \text { with a total of } \\
101 \text { Thai listed company } \\
\text { executives using SPSS } \\
\text { path analytical model to } \\
\text { analyze the obtained data }\end{array}$ & $\begin{array}{l}\text { competitive strategy positively } \\
\text { and significantly enhances firm } \\
\text { performance through performance } \\
\text { measurement }\end{array}$ & $\begin{array}{l}\text { there aren't clear causal } \\
\text { relationship among the two } \\
\text { aspects discussed }\end{array}$ & $\begin{array}{l}\text { future research could } \\
\text { consider the use of } \\
\text { longitudinal data to } \\
\text { ascertain more clearly } \\
\text { these causal } \\
\text { relationships }\end{array}$ \\
\hline
\end{tabular}




\begin{tabular}{|c|c|c|c|c|}
\hline $\begin{array}{l}\text { Authors } \\
\text { Publication }\end{array}$ & Methods & Key Findings & Limitations & Future Research \\
\hline Conaty (2012) & \begin{tabular}{lr}
\multicolumn{2}{c}{ preliminary case study of } \\
an Irish & $\mathrm{NPO} /$ public \\
sector & hybrid \\
organization &
\end{tabular} & $\begin{array}{l}\text { five organizational } \\
\text { characteristics/attributes are } \\
\text { identified as central to the } \\
\text { understanding of challenges in } \\
\text { performance management such as } \\
\text { inter-stakeholder relationships, } \\
\text { tensions across priority objectives, } \\
\text { cultural and institutional clashes, } \\
\text { power distribution and } \\
\text { interdependent stress }\end{array}$ & $\begin{array}{l}\text { the paper is a preliminary } \\
\text { exploration of the critical } \\
\text { organizational characteristics } \\
\text { and attributes }\end{array}$ & $\begin{array}{l}\text { Further performance } \\
\text { management research } \\
\text { in NPO/public sector } \\
\text { hybrid organizations } \\
\text { for further } \\
\text { identification, } \\
\text { performance } \\
\text { governance, } \\
\text { performance } \\
\text { framework ideal type } \\
\text { and other challenges in } \\
\text { hybrid settings }\end{array}$ \\
\hline Rhodes et al.,(2012) & $\begin{array}{l}\text { summarized in a table } \\
\text { and comparisons made to } \\
\text { generate additional } \\
\text { insights into the factors } \\
\text { that influence the shape } \\
\text { and speed of public } \\
\text { management evolution }\end{array}$ & $\begin{array}{l}\text { The paper finds that the Bouckaert } \\
\text { and Halligan framework for } \\
\text { analyzing public sector } \\
\text { performance management is } \\
\text { useful, albeit with some } \\
\text { modifications, the paper observes } \\
\text { that absent political } \\
\text { crisis/commitment, governments } \\
\text { will prioritize "external" } \\
\text { performance measures such as } \\
\text { customer service, participation } \\
\text { and transparency objectives over } \\
\text { "internal" performance measures } \\
\text { such as financial, staff } \\
\text { management and whole of } \\
\text { government reporting }\end{array}$ & $\begin{array}{l}\text { The paper doesn't go further } \\
\text { details in the empirical } \\
\text { findings and doesn't study the } \\
\text { linkage of performance } \\
\text { variables for public sector }\end{array}$ & $\begin{array}{l}\text { further studies can } \\
\text { examine public } \\
\text { administration reform, } \\
\text { and other factors that } \\
\text { affect performance } \\
\text { management in public } \\
\text { sector }\end{array}$ \\
\hline
\end{tabular}

